\author{
Удк 347 \\ DOI 10.24147/2542-1514.2018.2(4).30-42 \\ ПРАВОВЫЕ ПРОБЛЕМЫ ОБЕСПЕЧЕНИЯ РАВНЫХ УСЛОВИЙ РЕАЛИЗАЦИИ
КОНСТИТУЦИОННОГО ПРАВА НА ПОЛУЧЕНИЕ ОБЩЕГО ОБРАЗОВАНИЯ
}

А.С. Матненко

Омский государственный университет им. Ф.М. Достоевского, г. Омск, Россия

\author{
Информация о статье \\ Дата поступления - \\ 15 сентября 2018 г. \\ Дата принятия в печать - \\ 14 декабря 2018 г. \\ Дата онлайн-размещения - \\ 20 января 2019 г.

\section{Ключевые слова} \\ Права граждан, \\ конституционное право, право \\ на образование, школьное \\ образование, общее \\ образование, образовательное \\ законодательство, \\ правоприменение
}

\begin{abstract}
Исследуются вопросы правотворческой и правоприменильной практики, связанной с выбором гражданами Российской Федерации образовательных учреждений и программ при получении общего образования. Рассматриваются проблемы и конфликты, связанные с недостатками правового регулирования в этой сфере. Анализируется существующая в Российской Федерации «участково-территориальная» модель организации школьного образования, а также предусмотренные законодательством элементы конкурсного отбора при зачислении в школы. Охвачены как федеральный, так и региональный уровни правового регулирования, а также опыт зарубежных стран. Использованы материалы судебной практики.
\end{abstract}

\title{
LEGAL PROBLEMS OF ENSURING EQUAL CONDITIONS FOR REALIZATION THE CONSTITUTIONAL RIGHT TO EDUCATION
}

\section{Alexander S. Matnenko}

Dostoevsky Omsk State University, Omsk, Russia

\section{Article info}

Received - 2018 September 15 Accepted - 2018 December 14 Available online - 2019 January 20

\section{Keywords}

Citizens' rights, constitutional right, right to education, school education, General education, educational legislation, law enforcement
The subject of the paper is legal conditions for realization the constitutional right to education.

The purpose of the paper is to confirm or disprove the hypothesis that legal measures of realization of the right to education that are used in developed foreign countries can be used in Russia to improve Russian educational legislation.

The methodology. General scientific methods as analysis, synthesis, induction, deduction, comparison were used. The author also uses the formal legal interpretation of Russian judicial decisions as well as comparative legal method.

The main results and scope of their application. The court decisions supporting the principle of territorial consolidation of schools indicate that this principle does not exclude the possibility of citizens not residing in the fixed territory to enter the school of their choice. However, the implementation of this feature, due to the lack of legislative regulations of the procedure, can cause bias, corruption and other abuses of constitutional right to education. Inequality children's opportunities to enter the school due to their place of residence persists in the individual selection process. Situations where there are no clear and consistent rules for the provision school education inevitably generates numerous violations of citizens' rights and inequality based on the financial situation of parents. In Russia, there is no "waiting list", when children wishing to enroll in a particular school, would be taken to the vacant place. Accordingly, the adoption of such decisions by school administrations also lies in the plane of subjective discretion and causes corruption risks. China's experience is inter- 
esting because there are transparent, equal conditions for legal attraction of extra-budgetary funds to the school system, which do not turn access to education in the best schools into a corruption scheme or competition of parents ' incomes and do not infringe the rights of those who seek to enter them on the basis of their own achievements and knowledge. Speaking about the British experience, it is interesting to note that the lack of vacancies in the school itself can not be a reason for refusing to enroll a child in school.

Conclusions. The legal experience of developed countries, such as the United Kingdom, Germany, Austria, Japan, China, in regulating the grounds and procedures for the provision of school education can be successfully applied in order to improve the Russian legislation, which establishes the legal mechanisms for the implementation of the constitutional right to education.

\section{1. Введение}

В отличие от сегмента дошкольного образования школы в России формально полностью покрывают потребность в предоставлении образовательных услуг. В тех населенных пунктах, где школы отсутствуют либо работают в режиме начального общего образования, органы местного самоуправления обязаны организовать подвоз учащихся до школ, оказывающих необходимые образовательные услуги.

Однако отсутствие дефицита мест в системе российского школьного образования не снимает остроты проблемы равенства возможностей в рамках этой системы. Очевиден тот факт, что качество образовательных услуг, предоставляемых школами, разное. Оно может отличаться разительно даже в учреждениях, расположенных через дорогу друг от друга. Такая ситуация типична не только для России [1].

Разумеется, спрос на получение образовательных услуг лучшего качества высок и превышает доступное предложение. Каким образом законодательство регулирует доступ граждан к получению школьного образования?

\section{2. Регулирование доступа к школьному обра-} зованию в России

Так же, как и в случае с дошкольным образованием, здесь действует базовый принцип территориального преимущества. На основании части 3 статьи 67 Федерального закона от 29 декабря 2012 года № 273-Ф3 «Об образовании в Российской Федерации» (далее - Федеральный закон об образовании № 273-Ф3) за каждой школой закрепляется территориальный участки, проживающие на которых граждане обеспечиваются местами в школе в приоритетном порядке [2, с. 240; 3 с. 66; 4, с. 310].

\section{1. Территориальное закрепление школ}

Включению в закон указанной нормы предшествовала весьма неоднородная судебная практика, которая в том числе выражала позицию о недопустимости предоставления преимуществ при выборе об- щеобразовательного учреждения по признаку территории проживания.

Судами общей юрисдикции были признаны недействующими положения нормативных правовых актов ряда субъектов Российской Федерации и мунципальных образований, устанавливающих приоритеты при приеме детей в первый класс. Так, решением Московского городского суда от 13.04.2011 по заявлению прокурора города Москвы были признаны противоречащими федеральному законодательству и недействующими положения статьи 11 Закона города Москвы № 14 «Об общем образовании в городе Москве», согласно которым в первые классы государственных образовательных учреждений в первую очередь принимаются дети, проживающие в домах, расположенных в непосредственной близости от соответствующего образовательного учреждения; детисироты и дети, оставшиеся без попечения родителей; дети из многодетных семей; дети, имеющие братьев и сестер, обучающихся в данном образовательном учреждении; дети, которым федеральными законами и иными нормативными правовыми актами Российской Федерации, законами и иными нормативными правовыми актами города Москвы предоставлено преимущественное право при приеме в государственные образовательные учреждения, реализующие основную общеобразовательную программу соответствующего уровня.

В отсутствие законодательно установленных правил, регулирующих порядок приема детей в школы в условиях, когда количество желающих превышает количество доступных мест, отмена территориального приоритета породила крайне напряженную и конфликтную ситуцацию, прежде всего в крупных российских городах [5]. Вот как ее описывает журналист «Российской газеты»:

«Жесткий боевик под условным названием “Кто прорвется в первый класс?” с начала этого года страна смотрела практически в прямом эфире. В но- 
Правоприменение

2018. T. 2, № 4. С. 30-42

востных выпусках периодически появлялись сюжеты, похожие как близнецы-братья. Издерганные взрослые сутками штурмовали школы, вставая в огромные очереди затемно. Писали забытые списки, раздавали номерки и успокаивающие таблетки. Нервные граждане из очередей просто хотели записать в школы своих чад. Но желающих, как водится, было много. А мест в первых классах оказалось вдруг мало. Поэтому градус возмущения в этих очередях рос день ото дня. Доходило до оскорблений, а в особо нервных случаях до мордобоя и милиции. В телевизионных сюжетах менялись только названия школ и городов. А очереди были везде одинаковы. Но самые большие и скандальные битвы за право прийти в "свою" школу оказались в Москве» ${ }^{1}$.

Спорное решение Мосгорсуда было обжаловано в кассационном порядке Московской городской думой и отменено определением Верховного суда Российской Федерации 15 июня 2011 года. В определении отмечено, что правовое регулирование, при котором каждому гарантировано право на поступление в первый класс того образовательного учреждения, которое расположено в непосредственной близости от его места жительства, не может расцениваться как дискриминационное, ограничивающее право на общедоступное образование. Иное регулирование, по мнению высшей судебной инстанции, напротив, с определенной долей вероятности допускало бы возможность отказа в приеме в первый класс по мотивам отсутствия свободных мест детям, проживающим рядом со школой, умаляя право ребенка на доступность образования (в том числе доступность пешеходную).

Точка в спорах о территориальном закреплении школ была поставлена федеральным законодателем в Федеральном законе от 8 ноября 2011 года № 310-Ф3 «О внесении изменений в статьи 16 и 31 Закона Российской Федерации «Об образовании» в части обеспечения территориальной доступности муниципальных образовательных учреждений». Согласно внесенных изменений правила приема граждан в муниципальные образовательные учреждения для обучения по основным общеобразовательным программам начального общего, основного общего и среднего (полного) общего образования должны обеспечивать прием в указанные образовательные учреждения граждан, которые проживают на территории муниципального района, городского округа, закрепленной соответствующими органами местного самоуправления за конкретным муниципальным образовательным учреждением, и имеют право на получение общего образования. Чуть позже в несколько видоизмененной формулировке эта норма была включена в новый, действующий в настоящее время Федеральный закон об образовании № 273-Ф3.

Правила, о которых идет речь в вышеназванной норме, определены Приказом Минобрнауки России от 22 января 2014 г. № 32 «Об утверждении Порядка приема граждан на обучение по образовательным программам начального общего, основного общего и среднего общего образования» (далее - Порядок). В соответствии с пунктом 14 Порядка прием заявлений в первый класс для граждан, проживающих на закрепленной территории, начинается не позднее 1 февраля и завершается не позднее 30 июня текущего года. Для детей, не проживающих на закрепленной территории, прием заявлений в первый класс начинается с 1 июля текущего года до момента заполнения свободных мест, но не позднее 5 сентября текущего года.

Таким образом, дети, не проживающие на закрепленной территории, отсекаются от «не своей» школы датой подачи заявления, с наступлением которой вакантные места могут отсутствовать или иметь крайне ограниченное количество. По сути, территориальный принцип означает достаточно жесткую сегрегацию российских школьников, основанную в том числе на имущественном признаке. Как правило, лучшие школы, имеющие богатые традиции, расположены в престижных, наиболее привлекательных для проживания районах и частях населенных пунктов (исторических центрах, районах элитной застройки и т. п.). Соответственно, приоритетную, а иногда и исключительную возможность поступления в такие школы имеют дети из семей с высоким уровнем социального и материального положения.

Критерии определения границ территорий, закрепляемых за школами, законодательством прямо не определены. СанПиН 2.4.2.2821-10 «Санитарноэпидемиологические требования к условиям и организации обучения в образовательных учреждениях» определил нормативные расстояния пешеходной доступности общеобразовательных организаций в зависимости от типа местности и строительно-климатической зоны (от 300 метров к городской местности, до 4 км в сельской). Однако данные нормативы

\footnotetext{
1 Козлова. Н. Первоклассное решение // Российская газета.
} Федеральный выпуск № 5505 (129) от 17.06.2011. 
предназначены для проектирования и строительства школ и, строго говоря, не рассчитаны на процесс принятия решений об определении школьных микроучастков. Несмотря на то, что Верховный суд Российской Федерации в рамках рассмотрения дела по обжалованию вышеупомянутого решения Московского городского суда от 13 апреля 2011 г., указал на более широкое значение положений СанПиН, связав их с необходимостью территориального закрепления школ в интересах охраны здоровья детей, сами по себе эти положения не могут разрешить коллизии, возникающие при установлении границ школьных микроучастков. В частности, они не дают ответа на вопрос, как быть в том случае и по какому принципу выбирать дома для закрепления, если школа не в состоянии обеспечить прием всех детей, зарегистрированных на территории в пределах установленного радиуса (300 или 500 метров). По какому принципу производить закрепление, если в установленном радиусе расположено несколько школ? Поэтому нередко решения по конкретным участкам вызывают вопросы и недовольство со стороны граждан. Например, в случаях закрепления дома не за близлежащей, а за более удаленной школой. Гарантии того, что ребенок получит возможность зачисления в территориально ближайшую к нему школу, законодательством не установлены.

Показательны в этом смысле примеры из судебной практики в Пермской и Челябинской области.

В 2012 году многие жители г. Пермь были возмущены установленным в городе территориальным раскреплением школ. В результате принятого решения значительное количество детей было лишено возможности поступления в территориально наиболее близкие школы, их дома закреплялись за школами, расположенными на расстоянии киллометр и более, с необходомстью пересечения проезжей части. При этом имелась значительная несоразмерность в распределении закрепленных мест за гимназиями, лицеями, школами с углубленным изучением предметов, с одной стороны, и за обычными школами с другой ${ }^{2}$.

Прокурор г. Перми обратился в суд с заявлением о признании недействующим с момента принятия Перечня территорий г. Перми, закрепленных за муниципальными общеобразовательными учреждениями, утвержденного Постановлением Администрации города Перми от 30 марта 2012 г. № 132.

2 Подробно об этой ситуации см.: Соколова Т. Первый класс выбрали за вас // Пермский обозреватель. № 15 (565) от
Прокурор полагал, что «Перечень», нарушает права граждан на получение общедоступного основного образования, поскольку за частью образовательных учреждений закреплена значительная часть территории города Перми, а за другой частью образовательных учреждений - незначительная территория города Перми. В соответствии с распоряжением начальника Департамента образования администрации города Перми от 06.04.2012 г. № СЭД-084) 126-143 организован учет детей, подлежащих обязательному обучению в образовательных учреждениях реализующих программы общего образования, в связи с чем проведен анализ количества детей, проживающих на закрепленных территориях за образовательными учреждениями и количестве мест в первых классах, из которого следует, что количество мест для приема детей в первый класс недостаточно в тех образовательных учреждениях, за которыми закреплена значительная городская территория и количество детей, проживающих на данной территории, превышает количество мест в первых классах, установленных муниципальным заданием. В тоже время, указал прокурор, за частью образовательных учреждений, занимающихся либо углубленным изучением отдельных предметов, либо обеспечивающих дополнительную (углубленную) подготовку обучающихся по предметам гуманитарного, технического или естественно-научного профиля (статусные образовательные учреждения) закреплена незначительная часть территории и количество проживающих на данной территории детей, заведомо не покрывает потребность школы в первоклассниках. Кроме того, при закреплении территории города Перми за образовательными учреждениями не учтены требования СанПиН 2.4.2.2821-10 о территориальной доступности образовательных учреждений для детей, которая должна составлять не более 0.5 км.

Решением Ленинского районного суда г. Перми от 28 января 2013 года в удовлетворении заявления прокурора г. Перми отказано. Апелляционная инстанция (Пермский краевой суд) оставила решение в силе. В своих актах суды указали, в том числе на то, что п. 2.4 Раздела II, СанПиН 2.4.2.2821-10, которым предусмотрено, что при проектировании и строительстве городских общеобразовательных учреждений рекомендуется предусмотреть пешеходную доступность учреждений, расположенных на расстоянии от 0.3 до 0.5 км., относится к проектируемым и

14 апреля 2012 года; Суворова И. Правила черчения // «Российская газета - Неделя» - Пермский край № 6031. 
Правоприменение

2018. T. 2, № 4. С. 30-42

строящимся школам, тогда как в рассматриваемом случае речь идет о функционирующих школах.

В 2014 году Советский районный суд г. Челябинска рассмотрел дело по иску прокурора города Челябинска к администрации города Челябинска о признании незаконным, недействующим и отмене пункта 1 распоряжения администрации города Челябинска № 1077 от 27 февраля 2013 года о закреплении территорий за муниципальными образовательными учреждениями города Челябинска. В иске указывалось, что ряд жилых домов необоснованно, в нарушение требований СанПиН 2.4.2821-10 закреплен за образовательными учреждениями, расположенными на расстоянии от 0.6 до 1-48 км. Также в иск содержал доводы о дискриминационном характере пункта 1 оспариваемого распоряжения администрации, как нарушающего права граждан на общедоступное образование и указывал на преюдиции Определения Верховного Суда Российской Федерации № 5-Г11-106 от 15 июня 2011 года при разрешении гражданского дела по существу. Однако суд в удовлетворении иска отказал, так же, как и пермские суды, указав на рекомендательный характер требований пункта 2.4 СанПиН 2.4.2.2821-10 и их распространение на проектирование и строительство городских общеобразовательных учреждений, невозможность применения к ранее построенным зданиям общеобразовательных учреждений. Челябинский областной суд поддержал выводы суда первой инстанции.

Иными словами, какие-либо основания для судебной защиты прав граждан в связи закреплением жилых территорий за школами практически отсутствуют. Во-первых, органы местного самоуправления при принятии решений не связаны нормативными требованиями об условиях и критериях закрепления территорий. Во-вторых, как указал Пермский краевой суд в апелляционном определенииот 17.04.2013 по делу N 33-3486 обоспаривании постановления Администрации города Перми от 30.03.2012 г. № 132 «О закреплении территории города Перми за муниципальными общеобразовательными учреждениями», определяющее значение для разрешения данного спора имеет то обстоятельство, что оспариваемое «Постановление» не регламентирует порядок и основания приема детей в образовательные учреждения. Соответственно, данное «Постановление» не содержит и не может содержать положения, ограничивающие возможность реализации гражданами права на получение общедоступного среднего образования.

Вывод более чем спорный, но это вывод суда.
Точку в данном вопрос поставил Верховный суд Российской Федерации, который 16 сентября 2015 г. (определение № 5-АПГ15-55) рассмотрел апелляционную жалобу жительницы Москвы Анны Рябовой, которая просила отменить с момента принятия приложение к приказу столичного департамента образования от 22 ноября 2013 г. № 804 «О закреплении образовательных организаций за микрорайонами (территориями) города Москвы». Документ, в частности, закрепляет за расположенной рядом с МГУ гимназией № 1514 всего два близлежащих жилых дома. Дом, в котором зарегистрирована дочь заявительницы, находится в 30 м от учебного заведения, но, как и еще более 60 домов микрорайона, приписан к другой, более отдаленной и менее престижной школе. В результате семья, специально купившая квартиру в доме напротив выбранной ими гимназии, не смогла записать туда ребенка. Как указала высшая судебная инстанция в своем определении, «довод заявителя о том, что многоквартирный дом, в котором проживает дочь Рябовой А.П., расположен на территории, за которой закреплена иная образовательная организация (ГБОУ № 118), не свидетельствует о том, что такое распределение противоречит требованиям законодательства. Как усматривается из материалов дела и установлено судом, пешеходная доступность ГБОУ № 118 и Гимназии № 1514 находится в одном диапазоне, предусмотренном санитарно-эпидемиологическими требованиями к условиям организации обучения в общеобразовательных организациях, утвержденными постановлением Главного государственного врача Российской Федерации от 29 декабря 2010 года № 189».

Как правило, в судебных решениях, поддерживающих принцип территориального закрепления школ, указывается на то, что данный принцип не исключает возможность граждан, не проживающих на закрепленной территории, поступить в школу по своему выбору.

\section{2. Спорные вопросы зачисления в школы}

Однако реализация этой возможности, в силу отсутствия в законодательстве норм о порядке распределения между детьми «дефицитных» школьных мест, лежит в плоскости отношений, предельно уязвимой с точки зрения применения субъективного подхода, коррупционных и других злоупотреблений.

Федеральное регулирование в этой части ограничено возложением на образовательную организацию обязанности проинформировать население о наличии свободных мест для приема детей, не проживающих на закрепленной территории, не позднее 
1 июля (на информационном стенде, официальном сайте в сети Интернет, в средствах массовой информации).

Установлено также, что для таких детей прием заявлений в первый класс начинается с 1 июля текущего года до момента заполнения свободных мест. Указанная норма, при отсутствии других конкретизирующих правил, оставляет целый ряд вопросов. В каком порядке фиксируется время подачи заявления? Каким периодом времени определяется момент заполнения свободных мест? В каком порядке информируются граждане о наступлении этого момента? Что считать заполнением свободного места: подачу гражданином заявления или издание распорядительного акта о зачислении ребенка в школу?

Из текста Порядка не вполне ясен также срок издания распорядительного акта о зачислении «незакрепленных" детей в школу.

В соответствии с пунктом 14 Порядка зачисление оформляется распорядительным актом в течение 7 рабочих дней после приема документов. Однако из текста не понятно, относится это ко всем детям, или только проживающим на закрепленной территории. И что значит - «после приема документов»: после приема отдельного взятого заявления или после наступления предельного срока для подачи заявлений?

Еще большую неопределенность вносит пункт 16 Порядка, согласно которому при приеме на свободные места детей, не проживающих на закрепленной территории, преимущественным правом обладают дети граждан, имеющих право на первоочередное предоставление места в образовательную организацию в соответствии с законодательством Российской Федерации и нормативными правовыми актами субъектов Российской Федерации. Сам термин «первоочередное» предполагает наличие некой «очереди», в том время как «очередь» в данном случае не формируется.

Еще более неопределенный характер носит положение пункта 4 статьи 67 Федерального закона об образовании № 273-Ф3:

«В случае отсутствия мест в государственной или муниципальной образовательной организации родители (законные представители) ребенка для решения вопроса о его устройстве в другую общеобразовательную организацию обращаются непосредственно в орган исполнительной власти субъекта Российской Федерации, осуществляющий государ- ственное управление в сфере образования, или орган местного самоуправления, осуществляющий управление в сфере образования».

Порядок рассмотрения уполномоченными органами управления таких обращений, условия распределения ими мест в общеобразовательных организациях нормативно не урегулированы.

\section{3. Рыночная экономика и доступ к образованию}

Ситуации, когда отсутствуют ясные, непротиворечивые правила предоставления мест в школах, с неизбежностью порождает многочисленные нарушениях прав граждан, неравенство, основанное на материальном положении родителей [7-12]. Значительное распространение получили факты зачисления детей при условии перечисления добровольных денежных пожертвований в фонд школы. Судя по тем фактам, которые находят отражение в средствах массовой информации, так называемые «вступительные взносы» в школу могут достигать несколько сотен тысяч рублей. Так, в Москве вступительные взносы (легальный и нелегальные) колеблются от пяти до трехсот тысяч рублей. На Западе и Юго-Западе столицы они достигают максимальной цифры ${ }^{3}$.

Явление приобрело столь значительные масштабы, что на него вынужден был отреагировать Президент Российской Федерации на встрече с активом партии «Единая Россия» 28 апреля 2011 года. В диалоге с матерью троих детей, лишенной возможности устроить ребенка в близлежащую школу, Д.А. Медведев назвал сложившуюся ситуацию «игрой без правил», а поборы с родителей «цивилизованной формой взятки».

На повсеместное распространение незаконных денежных сборов с родителей под видом благотворительной помощи и добровольных пожертвований на протяжении многих лет указывают органы прокуратуры. Дважды (в 2005 и 2010 годах) Генеральная прокуратура Российской Федерации по итогам проведенных проверок вносила представления Министру образования и науки Российской Федерации А. Фурсенко об устрании данных нарушений. Однако за последние восемь лет положение существенным образом не изменилась, о чем свидетельствуют результаты многочисленных прокурорских проверок в различных регионах России: Самарская область, Приморский край, Забайкальский край, Республика Калмыкия и др.

Сложность выхода из сложившейся ситуации, изменения ее по существу заключается в том, что по

3 Янс Г. Страшный урок Андрея Кудоярова // Московский комсомолец, № 25769 от 12 октября 2011. 
закону образовательным организациям не запрещено принимать благотвирительную финансовую помощь, а любой гражданин или организация вправе ее оказывать, что гарантировано Федеральным законом от 11 августа 1995 года № 135-Ф3 «О благотворительной деятельности и благотворительных организациях». Претензии к администрации школы могут возникнуть только при наличии в ее действиях формальных признаков принуждения родителей к внесению денежных взносов: предоставление им договоров или квитанций с заранее определенными суммами, заключение договоров и тому подобное. В том же случае если соблюдена видимость добровольности и документы оформлены надлежащим образом у прокуратуры и других правоохранительных органов нет оснований для принятия мер реагирования. При отсутствии четко определенных правил это создает почву для практически безнаказанной купли-продажи мест в образовательных организациях.

Кроме того, объектом купли-продажи стало масто «прописки» (регистрации), дающее право на зачесление ребенка в желаемое образовательное учреждение. О масштабах этого "бизнеса» свидетельствует статистика: например, в г. Екатеринбурге в 2017 году с 1 по 10 февраля за первые десять дней периода приема заявлений по территориальному принципу более трети (36 процентов) зачисленных первоклассников имеют временную регистрацию; в некоторых школах их доля достигает 70 процентов. Называется и стоимость такой регистрации от 4 тысяч рублей до 50 тысяч рублей. В Новосибирске можно купить "школьную прописку» за 7 тысяч рублей, в Красноярске - за 5 тысяч 4 .

Также неурегулированным остается вопрос о заполнении в школах вакатных мест, образующихся в течение учебного года вследствие перехода ученика в другую школу или иных обстоятельств. В России нет такого понятия как "лист ожидания», находящиеся в котором дети, желающие поступить в ту или иную школу, принимались бы на освободившееся место. Соответственно, принятие таких решений администрациями школ также лежит в плоскости субъектвного усмотрения и коррупционных рисков.

4. Исключения из принципа территориального закрепления школ

Единственный механизм, дающий школьнику возможность выбора школы, исходя из его способ- ностей, академических достижений, предусмотрен пунктом 5 статьи 67 Федерального закона об образовании № 273-Ф3, допускающем проведение индивидуального отбора при приеме либо переводе в государственные и муниципальные образовательные организации для получения основного общего и среднего общего образования с углубленным изучением отдельных учебных предметов или для профильного обучения в случаях и в порядке, которые предусмотрены законодательством субъекта Российской Федерации.

Приведенная норма, хотя и не содержит прямого исключения из принципа приоритета места проживания при приеме в школу, но все же создает конкурентную основу доступа граждан к обучению в специализированных классах. Ее большим недостатком является отсылочный характер, в полном объеме передающий правовое регулирование этого важнейшего вопроса, включая саму возможность отбора, на уровень регионального законодательства.

Анализ нормативных правовых актов субъектов Российской Федерации показывает ошибочность такого подхода федерального законодателя, поскольку какой-либо стройной, законченной, а тем более единообразной системы государственных гарантий справедливого и равноправного отбора школьников на региональном уровне не сложилось.

Прежде всего следует отметить, что только в единичных случаях основания и порядок отбора регулируются законами субъектов Российской Федерации. В абсолютном большинстве регионов соответствующие полномочия закреплены за органами исполнительной власти, которые, в свою, очередь нередко, передают решение ключего вопроса - о критерях конкурсного отбора - на уровень непосредственно образовательных учреждений. Например, полностью отсылочный в этой части характер имеет постановление Правительства Пензенской области от 12 сентября 2014 года № 641-п «Об утверждении случаев и порядка организации индивидуального отбора при приеме либо переводе в государственные и муниципальные образовательные организации Пензенской области для получения основного общего и среднего общего образования с углубленным изучением отдельных учебных предметов или для профильного обучения». Согласно пункту 7 утвержденного им Порядка критерии проведения индивидуального отбора несовершеннолетних

\footnotetext{
${ }^{4}$ Дубичева К. Первоклашка Мишка, где твоя прописка? // Российская газета. Федеральный выпуск № 7204 (38) от 20.02.2017.
} 
граждан устанавливаются образовательной организацией самостоятельно и утверждаются распорядительным актом образовательной организации.

Похожие отсылочные положения имеют нормативные правовые акты Архангельской, Амурской, Мурманской, Нижегородской, Тюменской, Свердловской, Тульской, Рязанской, Воронежской и ряда других областей.

Как следствие, формы и условия индивидуального отбора могут различатся не только по регионам, но и по школам одного населенного пункта. При этом нередко школьники информируются об этом за 10-30 дней до дня отбора, что крайне ограничивает время для подготовки.

На практике далеко не все школы, имеющие классы с углубленным изучением отдельных предметов или профильные классы, проводят индивидуальный отбор в них. При этом законодательство не дает ясного ответа на вопрос является ли проведение отбора таком случае правом или обязанностью школы.

Лишь в некоторых субъектах Российской Федерации предусмотрено утвреждение органами управления образование перечня образовательных организаций, в которых проводится индивидуальный отбор.

Формально декларируемый конкурентный принцип отбора, тем не менее, как правило, не исключает территориального ценза. В большинстве случаев утвержденные порядки содержат ограничения для лиц, обучающихся в других школах, и преимущества для тех детей, которые уже обучаются в организации, осуществляющий отбор, или факт проживания на закрепленной территории. Например, в соответствии с пунктом 5 статьи 4 Закона Хабаровского края от 30 октября 2013 года № 316 при принятии решения об индивидуальном отборе, в случае превышения количества поданных заявлений над общим количеством мест в классе (классах) с углубленным изучением отдельных учебных предметов или в классе (классах) профильного обучения и при равенстве показанных обучающимися результатов тестирования (собеседования) по соответствующим

\footnotetext{
5 Пункт 4 Порядка организации индивидуального отбора обучающихся при приеме либо переводе в государственные и муниципальные образовательные организации, расположенные на территории Новгородской области, для получения основного общего и среднего общего образования с углубленным изучением отдельных учебных предметов или для профильного обучения, утвержденного Постановлением Правительства Новгородской области от 12 августа 2014 года № 429.
}

учебным предметам или результатов государственной итоговой аттестации по профильным предметам, учитываетсяпроживание обучающегося на территории, закрепленной за образовательной организацией. В Новгородской области прием обучающихся в образовательные организации, реализующие общеобразовательные программы углубленного изучения отдельных учебных предметов и (или) профильного обучения осуществляется вне зависимости от места жительства обучающихся только при наличии свободных мест ${ }^{5}$.

Согласно пункту 10 Порядка, установленного постановлением Правительства Республики Коми от 4 апреля 2014 года № 137, прием в образовательную организацию обучающегося из другой образовательной организации, реализующей общеобразовательную программу соответствующего уровня, осуществляется при наличии свободных мест.

Аналогичные положения, предоставляющие право учащимся других школ участвовать в отборе только по остаточному принципу (при наличии свободных мест), содержатся в нормативных правовых актах Приморского, Краснодарского краев, Волгоградской, Омской областей и многих других регионов.

Закнодательство субъектов Российской Федерации при этом не содержит требований по минимальным квотам мест, на которые могли бы претендовать учащиеся других образовательных организаций.

В Свердловской области провозглашено, что комплектование классов с углубленным изучением отдельных предметов, классов профильного обучения производится независимо от места проживания обучающихся ${ }^{6}$. Однако образовательные организации самостоятельно устанавливают квоты приема учеников из других школ ${ }^{7}$.

Таким образом, неравенство возможностей детей, обусловленное местом их проживания, сохраняется и при проведения индивидуального отбора в школы.

Существуют и другие ограничения дискриминационного характера. Например, в соответствии с

\footnotetext{
6 Пункт 3 Порядка организации индивидуального отбора при приеме либо переводе в государственные образовательные организации Свердловской области и муниципальные образовательные организации для получения основного общего и среднего общего образования с углубленным изучением отдельных учебных предметов или для профильного обучения, утвержденного постановлением Правительства Свердловской области от 27 декабря 2013 года № 1669-ПП.

7 См., напр., приказ директора Гимназии № 9 г. Екатеринбурга № 18 от 25 февраля 2015 года.
} 
пунктом 6 порядка индивидуального отбора, утвержденного постановлением Правительства Республики Хакасия от 31 декабря 2014 года № 732, перевод обучающегося из другой образовательной организации в образовательную организацию для получения основного общего и среднего общего образования с углубленным изучением отдельных предметов осуществляется в случае реализации первой общеобразовательных программ соответствующего уровня.То есть право на перевод обусловлено не академическими достижениями и способности индивида, а фактом обучения в школе, реализующей аналогичные образовательные программы.

В несколько видоизменном виде (в качестве преимущества при поступлении) данное условие определяется в нормативных правовых актах большинства субъектов Российской Федерации. В частности, в Тюменской области преимущественным правом приема либо перевода на обучение в образовательные организации (классы) пользуются обучающиеся, принимаемые в образовательную организацию в порядке перевода из другой образовательной организации, если они получали основное общее или среднее общее образование в классе с углубленным изучением соответствующих отдельных учебных предметов либо в классе соответствующего профильного обучения (пп. 3 п. 27 Порядка).

Отдельно следует остановиться на вопросе о формах и критериях индивидульного отбора. Законодательство субъектов Российской Федерации предусматривает, в основном, две формы отбора:

1) по существующим достижениям, подтверждаемым документально;

2) по результатам специальных вступительных испытаний.

Иногда предусматривается только одна форма отбора, иногда - их сочетание. Кроме того, как уже отмечалось, используются критерии, характеризующие не личность ребенка, а место его жительства или учебы.

Первая форма отбора потенциально имеет под собой достаточно объективную основу. Значительным шагом вперед стало внедрение с 2017 года в российских школах промежуточной аттестацией выпускников младшей школы (окончивших четыре класса). Аттестация проводится в централизованном порядке, на принципах, схожих ЕГЭ, с использованием единых контрольно-измерительных материалов и методик, что обеспечивает сопоставимость ее результатов. Однако действующие нормативные правовые акты субъектов Российской Федерации, устанавливающие пра- вила отбора, за редкими исключениями, фактически игнорируют показатели аттестации либо учитывают их в системе с другими показатели успеваемости и достижениями учащегося, которые носят более субъективный характер. Показатели успеваемости не всегда отражают реальный уровень подготовки учащихся. Реальная «цена» оценок может существенно отличаться и ученики школ с более высоким уровенм требований к знанием и объективности в их оценке могут оказаться в невыгодных условиях при проведении индивидуального отбора.

Что касается второй формы отбора - специальных вступительных испытаний, - то нормативными правовыми актами субъектов Российской Федерации их процедуры и содержание не регулируются даже в части самых общих, принципиальных моментов, обсепчивающих объективность и равенство условий их проведения. Как правило, содержится только указание на вид испытания (например, собеседование или тестирование). Все остальное (принципы построения содержательной части испытания, темы или вопросы, критерии определения результатов и т. д.) в лучшем случае определяется локальными актми самой школы, а часто и вовсе не получает какого-либо документального закрепления. Это не только затрудняет качественную и на равных условиях подготовку к испытанию, но и создает широкие возможности для проявления субъективного и, не исключено, коррупционного, подхода к оценке его результатов.

Возможность доступа граждан к более качественному обучению снижается не только вышеперечисленными факторами, но и тем, что согласно нормативным требованиям обучение в школах с углубленным изучением отдельных предметов, в гимназиях и лицеях возможно только в одну смену, что уменьшает их проектную наполняемость по сравнению с обычными школами в два раза.

5. Мировой опыт реализации права на образование

Переходя от российских реалий к мировой практике, следует отметить, что в ней существует много примеров организации доступа детей к услугам школьного образования, направленных на преодоление различий в социальном и экономическом статусе семей, субъективного и несправедливого распределения мест в школах [13].

Так, в Китае публичные средние общеобразовательные школы, начинающие обучение с 7 класса, подразделяются на участковые (территориальные) и элитные. В среднем в городах количество мест в 
элитных школах составляет 20 процентов от общего количества мест. Исторически, элитные школы создавались для приема учащихся исключительно по результатам вступительных экзаменов. С конца 1990 годов, когда в китайских школах отказались от вступительных испытаний в рамках обязательного 9-летнего обучения, система приема в элитные школы была изменена, разделившись на две квоты. Первая - для талантливых и одаренных детей, победителей академических, творческих и спортиных состязаний. Вторая (после заполнения первой) - для лиц, выбыраемых по результатам лоттереи, с последущим внесением платы за обучение, предельный размер которой устанавливается органами власти (в среднем около 400 американских долларов в год). Лотерея проводится с использованием технологий и наблюдателей, посволяющих исклчить какие-либо нарушения при ее проведении. Конкурс составляет в среднем 3-4 человека на место. По окончании обязательного девятилетного школьного образования лица, желающие получить полное общее образование, проходят процедуру отбора и зачисления в старшую среднюю школу на основании результатов национального экзамена (жанкао) по семи предметам. В наиболее престижных школ могут устанавливаться квоты для лиц, набравших количество баллов не достаточное, но близкое к проходному (в диапазоне 2 баллов) и готовых заплатить за обучение. При этом сумма оплаты зависит от количества набранных баллов. Например, обечение ученика, которому не хватило двух баллов, будет стоить в четыре раза дороже обучения в случае нехватки 0,5 балла.

Опыт Китая интересен тем, что созданы прозрачные, равные для всех условиях легального привлечения внебюджетных средств в систему школьного образования, не превращающие доступ к обучению в лучших школах в коррупционную схему или состязание доходов родителей и не ущемлюящие права тех, кто стремится поступить в них на базе собственных достижений и знаний.

В Великобритании (Англии и Северной Ирландии) наряду с обычными школами, принимающими учеников по территориальному принципу без вступительных испытаний, существует система «селективных» школ, набор в которые осуществляется результатам экзамена «11+» (сдается с 10 лет, в последний год начальной школы или после ее окончания; включает в себя тест по арифметике, сочинение и тест на общие знания и логику). Прообраз этой системы был

8 Harrison A. Lotteries "used more" to decide on school place // www. bbc.com/news/education-26354648; Noden Ph. How заложен Актом об образовании принятым британским парламентом в 1944 году. В нее входили так называемые грамматические школы "grammar schools», технические и современные школы. Зачисление в них осуществлялось по результатам экзамена $11+$, который был введен в этом же году.

С 2007 года в Англии действует Кодекс поступления в школы, принятый на основании Акта о школьных стандартах и правилах 1998 года и Акта об образовании и инспекциях 2006 года. Это 100-страничный документ, подробнейшим образом регулирующий отношения, возникающие при приеме детей в английские школы. Его главная цель, как обозначено в самом Кодексе, - реализация стремления Правительства создать школьную систему, которая бы несла в себе лучшие качества и справедливость, развивая таланты и потенциал каждого ребенка, независимо от его положения; систему, где бы все родители чувствовали, что имеют одинаковые возможности в выборе школы для своих детей.

На основании вышензванных нормативных актов помимо полностью селективных школ действуют также частично селективные школы, около10 процентов мест в которых заполняется по результатам эказмена $11+$.

Кроме того, установлена система критериев и правил отбора учащихся в обычные (неселективные школы) в случае, если количество заявлений о приеме превышает число имеющихся свободных мест, что достаточно частое явление, особенно в престижных, популярных школах. В этом случае используются два основных метода: 1) деление и отбор по группам (banding) и 2) случайная выборка, или лоттерея (random allocation, lottery). Применяются они либо по отдельности, либо в комбинации, с учетом установленных приоритетов. Например, приоритет имеют дети, чьи братья или сестры уже учатся в соответствующей школе.

Деление и отбор по группам осуществлениятся по результатам оценки заний и способностей учащихся. Группы формируются по мере убывания академических показателей, и каждая группа имеет пропорциональную квоту для зачисления в школу, с тем чтобы обеспечить для поступления в престижные школы детям с различным уровнем подготовленности.

Количество британских школ, использующих методы отбора по группам и лоттерии, сравнительно невелико (121 и 42, соответственно, по данным 2013 года), но и их количество ежегодно растет ${ }^{8}$.

ballots and banding are shaking up school admissions // The Conversation, 27.02.2014. 
Говоря о британском опыте, интересно отметить тот факт, что отстутствие вакантных мест в школе само по себе не может являться основанием для отказа в зачислении ребенка в школу. Такое решение было принято Верховным судом Англии, рассмотревшим жалобу матери ребенка, которой по этому основанию было отказано в зачислении и предложено поступление в другую школу. Суд постановил, что школа обязана предоставить место ребенку, если это не приведет к нарушению интересов уже обучающих в ней детей ${ }^{9}$.

Одна из самых селективных систем школьного образования - в Германии. Уже после окончания первой ступени образования, с 10-летнего возраста дети, по показателям успеваемости и тестовых испытаний, распределяются по трем видам школ (Gymnasium, Realschulen, Hauptschulen) рассчитанных на получение в дальнейшем, соответственно, университетского и техническо-прикладного образования.

В Японии полностью на конкурентной, селективной основе осуществляется набор для обучения на завершающей ого образования. Схожая система существует в Австрии, где стадии школьного образования подразделяются на академическое и техническое направления. Зачисление производится по результатам вступительных экаменов и показателей успеваемости в предшествующий период обучения.

В Казахстане создана сеть государственных интеллектуальных школ физико-математической и химико-биологческой направленности, действующих на основании Закона Республики Казахстан от 19 января 2011 «О статусе «Назарбаев Университет», «Назарбаев Интеллектуальные школы» и «Назарбаев Фонд». Для обучения в школах, начиная с 7-го класса, на конкурсной основе предоставляются образовательные гранты первого Президента Республики Казахстан.

Правилами проведения конкурса предоставляются равные права для претендентов, независимо от их социально-экономического статуса, маста проживания и состояния здоровья.

Конкурс состоит из двух этапов. На первом этапе проводится комплексное тестирование претендентов по профильным предметам, соответствующим направлениям школ, а также по казахскому, русскому и английскому языкам. Комплексное тестирование является отборочным ко второму этапу. K нему допускаются претенденты, набравшие $40 \%$ и более правильных ответов от общего количества вопросов. На втором этапе проводятся письменные экзамены по профильным предметам. Гранты присуждаются претендентам, набравшим более высокие баллы по результатам конкурса. При этом формируется резервный список, кандидатам из которого гранты предоставляются в случае появления вакантного места в школе в течение учебного года. Конкурс проводится республиканской комиссией, возглавляемой Министром образования и науки Республики Казахстан.

\section{6. Выводы}

Опыт развитых государств, таких, как Великобритания, Германия, Австрия, Япония, Китай в регулировании оснований и процедур предоставления школьного образования может быть успешно применен в целях совершенствования российского законодательства, закрепляющего правовые механизмы реализации конституционного права на образование.

\section{СПИСОК ЛИТЕРАТУРЫ}

1. БРИКС: контуры многополярного мира: монография / О.А. Акопян, Н.М. Бевеликова, К.М. Беликова и др.; отв. ред. Т.Я. Хабриева. - М.: ИЗиСП, Юриспруденция, 2015. - 300 с.

2. Образовательное законодательство России. Новая веха развития: монография / Л.В. Андриченко, В.Л. Баранков, Б.А. Булаевский и др.; под ред. Н.В. Путило, Н.С. Волковой. - М.: ИЗиСП, 2015. - 480 с.

3. Шугрина Е.С. Территориальные пределы юрисдикции органов местного самоуправления (на примере школьного образования) // Российский юридический журнал. - 2018. -№ 3. - С. 61-71.

4. Судебная практика в современной правовой системе России: монография / Т.Я. Хабриева, В.В. Лазарев, А.В. Габов и др.; под ред. Т.Я. Хабриевой, В.В. Лазарева. - М.: ИЗиСП, НОРМА, ИНФРА-М, 2017. - 432 с.

5. Лунгу Е.В. Конституционные правоотношения в социальной сфере / Е.В. Лунгу // Социальное и пенсионное право. - 2018. - № 3. - С. 17-21.

\footnotetext{
9 Paton G. Schools can still admit pupils when full // The Telegraph. 16.10.2009
} 
6. Пешин Н.Л. Проблемы и перспективы экономического и социального развития местного самоуправления / Н.Л. Пешин // Конституционное и муниципальное право. - 2017. - № 12. - С. 58-62.

7. Калигин М.Б. Опыт работы прокуратуры Саратовской области по защите прав детей при обеспечении общедоступного и бесплатного образования / М.Б. Калигин, Д.Х. Беккалиев // Прокурор. - 2016. - № 3. - С. 7678.

8. Косова О.Ю. Обеспечение доступности образования для несовершеннолетних // Законность. - 2017. - № 4. - C. 6-10.

9. Санникова Л.В. Гражданско-правовые и публичные услуги: проблемы соотношения / Л.В. Санникова // Сфера услуг: гражданско-правовое регулирование: сборник статей / под ред. Е.А. Суханова, Л.В. Санниковой. - М.: Инфотропик Медиа, 2011. - 240 с.

10. Горбунова О.Н. Фонды оплаты труда в государстве - объект изучения финансового права / О.Н. Горбунова // Финансовое право. - 2012. - № 11. - С. 3-6.

11. Савинский А.В. Бытовая коррупция в сфере медицины и образования: вопросы криминализации / A.B. Савинский // Журнал российского права. - 2018. - № 11. - С. 152-160. - DOI: 10.12737/art_2018_11_15.

12. Николаева Ю.В. К вопросу о стратегии и видах государственной политики в сфере защиты прав несовершеннолетних / Ю.В. Николаева // Адвокат. - 2011. - № 5. - С. 57-63.

13. Козырин А.Н. Право на образование в конституциях и законодательстве зарубежных стран / А.Н. Козырин // Реформы и право. - 2016. - № 4. - С. 31-39. C. 35 .

14. Кривченко А.В. Отчет о конференции / А.В. Кривченко // Юридическая психология. - 2010. - № 2. -

15. Манцуров А.Ю. Система образовательных учреждений Министерства общественной безопасности Китайской Народной Республики / А.Ю. Манцуров // Административное и муниципальное право. - 2009. № 9. - С. 49-51.

\section{REFERENCES}

1. Khabrieva T. Ya. (ed.). BRICS: the contours of the multipolar world: monograph. Moscow, Institute of legislation and comparative law Publ., 2015. 300 p. (In Russ.).

2. Putilo N.V., Volkova N.S. (eds.). Educational legislation of Russia. A new milestone of development: monograph. Moscow, Institute of legislation and comparative law Publ., 2015.480 p. (In Russ.).

3. Shugrina E. S. Territorial limits of jurisdiction of local governments (on the example of school education). Rossiyskiy yuridicheskiy zhurnal = Russian legal journal, 2018, no. 3, pp. 61-71. (In Russ.).

4. Khabrieva T. Ya., Lazarev V.V. (ed.). Judicial practice in the modern legal system of Russia: monograph. Moscow, Institute of legislation and comparative law Publ., NORMA, INFRA-M Publ., 2017. 432 p. (In Russ.).

5. Lungu E. V. Constitutional legal relations in the social sphere. Sotsial'noe i pensionnoe pravo $=$ Social and pension law, 2018, no. 3, pp. 17-21. (In Russ.).

6. Peshin N. L. Problems and prospects of economic and social development of local self-government. Konstitutsionnoe i munitsipal'noe pravo = Constitutional and municipal law, 2017, no. 12, pp. 58-62. (In Russ.).

7. Kaligin M. B., Bekkaliev D. H. Experience of Prosecutor's office of Saratov region for the protection of children's rights while ensuring public and free education. Prokuror, 2016, no. 3, pp. 76-78. (In Russ.).

8. Kosova O. Y. Providing access to education for juveniles. Zakon = Law, 2017, no. 4, pp. 6 - 10.

9. Sannikova L. V. Civil and public services: problems of correlation, in:. Sukhanov E. A, Sannikova L. V. (eds.). Services: civil regulation. Moscow, Infotropic Media, 2011. 240 p. (In Russ.).

10. Gorbunova O. N. Payroll in the state-the object of study of financial law. Finansovoe pravo = Financial law, 2012, no. 11, pp. 3-6. (In Russ.).

11. Savinskiy A. V. Domestic corruption in the field of medicine and education: issues of criminalization. Zhurnal rossiyskogo prava = Journal of Russian law, 2018, no. 11, pp. 152 - 160. DOI: 10.12737/art_2018_11_15. (In Russ.).

12. Nikolaeva Yu.V. A question of strategy and types of the state policy in the field of protection of the rights of minors. Advokat, 2011, no. 5, pp. 57-63. (In Russ.).

13. Kozyrin A.N.. The right to education in the constitutions and legislation of foreign countries. Reformy $i$ pravo, 2016, no. 4, pp. 31-39. (In Russ.). 
14. Krivchenko A.V. Conference report. Yuridicheskaya psihologiya = Legal psychology, 2010, no. 2, p. 35. (In Russ.).

15. Mantsurov, A. Y. System of educational institutions of the Ministry of public security people's of Republic of China. Administrativnoe i munitsipal'noe pravo = Administrative and municipal law, 2009, no. 9, pp. 49-51. (In Russ.).

\section{ИНФОРМАЦИЯ ОБ АВТОРЕ}

Матненко Александр Сергеевич - доктор юридических наук, профессор кафедры государственного и муниципального права

Омский государственный университет им. Ф.М. Достоевского

644077, Россия, г. Омск, пр. Мира, 55а

e-mail: kafedragmp@mail.ru

SPIN-код: 4023-3647; AuthorID: 380006

\section{БИБЛИОГРАФИЧЕСКОЕ ОПИСАНИЕ СТАТЬИ}

Матненко А.С. Правовые проблемы обеспечения равных условий реализации конституционного права на получение общего образования / А.С. Матненко // Правоприменение. - 2018. - Т. 2, № 4. - C. 30-42. - DOI: 10.24147/2542-1514.2018. 2(4).30-42.

\section{INFORMATION ABOUT AUTHOR}

Alexander S. Matnenko - Doctor of Law, Professor, Department of State and Municipal Law Dostoevsky Omsk State University

55a, Mira pr., Omsk, 644077, Russia

e-mail: kafedragmp@mail.ru

SPIN-code: 4023-3647; AuthorID: 380006

\section{BIBLIOGRAPHIC DESCRIPTION}

Matnenko A.S. Legal problems of ensuring equal conditions for realization the constitutional right to education. Pravoprimenenie = Law Enforcement Review, 2018 , vol. 2 , no. 4 , pp. $30-42$. DOI: $10.24147 / 2542-$ 1514.2018.2(4).30-42. (In Russ.). 